\title{
PERBEDAAN HASIL BELAJAR DENGAN MENGGUNAKAN STRATEGI PEMANFAATAN PERPUSTAKAAN SEKOLAH SEBAGAI SUMBER BELAJAR SISWA SDN KOTA BENGKULU
}

\author{
Khamilla Andina Sari \\ Program Studi PGSD FKIP Universitas Bengkulu \\ Herman Lusa \\ Program Studi PGSD FKIP Universitas Bengkulu \\ Syahril Yusuf \\ Program Studi PGSD FKIP Universitas Bengkulu
}

\begin{abstract}
The aim of this research is to determine the differences in student learning outcomes by using the school library utilization strategy as learning resources in the civics studies in grade V SD Negeri 82 Kota Bengkulu. This research is a quantitative research. The design of this research was Quasi Experimental Design with design types The Matching Only pretest-posttest control group design, where taking the test twice before and after the treatment in the sample class. Subjects in this research are the students of fifth grade of SDN 82 Kota Bengkulu which consists of the VA class as the experimental class and the VB class as the class control. The research instrument used is forms of test sheet multiple choices given by the pretest (before giving treatment) and posttest (after giving treatment). The data of this study was analyzed by using inferential analysis $T$-test. The results showed by using $t$-test $t_{\text {count }} 5,64$ and $t_{\text {tabel }} 2,00$. So $t_{\text {count }}(5,64)>t_{\text {tabel }}(2.00)$. By the result, it can be concluded that there are differences in student learning outcomes by using the school library utilization strategy as learning resources in the civics studies in grade V SD Negeri 82 Kota Bengkulu.
\end{abstract}

Keywords: Learning Outcomes, Strategies, School Library, , PKn Lesson

\section{PENDAHULUAN}

Informasi di era globalisasi telah menjadi kebutuhan utama dalam kehidupan manusia. Perkembangan ilmu pengetahuan dan semakin meningkatnya penyebaran informasi mendorong manusia selalu ingin tahu tentang suatu hal yang dapat memperluas wawasannya. Informasi dibutuhkan untuk semua lapisan masyarakat,dan salah satunya yaitu siswa. Adapun kebutuhan informasi seorang siswa yaitu terkait dengan perannya sebagai pelajar yang membutuhkan informasi tentang tugas-tugas sekolah dan materi pelajaran. Mengingat beragamnya kebutuhan informasi siswa maka sangat dibutuhkan fasilitas yang dapat memenuhi kebutuhan informasi yang siswa perlukan. Salah satu fasilitas sekolah yang dapat memenuhi kebutuhan informasi siswa yaitu perpustakaan sekolah. Hal ini sejalan dengan Peraturan Pemerintah Nomor 19 tahun 2005 tentang Standar Nasional Pendidikan pasal 42 menyebutkan bahwa sekolah wajib memiliki perpustakaan. Perpustakaan sekolah merupakan salah satu sumber belajar yang sangat penting yang memungkinkan tenaga kependidikan dan siswa memperoleh kesempatan untuk memperluas dan memperdalam pengetahuan dengan membaca bahan pustaka yang ada di perpustakaan sekolah. 
Kenyataannya berdasarkan observasi awal yang dilakukan peneliti di perpustakaan Sekolah Dasar Negeri 82 Kota Bengkulu pada menunjukkan bahwa perpustakaan kurang diminati oleh siswa dan hanya menjadi pajangan sekolah untuk mengoleksi buku-buku. Keinginan siswa ke perpustakaan untuk memanfaatkan perpustakaan sekolah sebagai ruang untuk belajar masih kurang. Rendahnya kemauan untuk belajar ke perpustakaan sekolah disebabkan juga oleh peran guru yang kurang dalam memotivasi siswanya untuk memanfaatkan perpustakaan sekolah sebagai sumber belajar. Siswa hanya menerima pembelajaran yang diberikan oleh guru yang mengajar di kelas, tanpa memanfaatkan fasilitas yang ada di sekolah yaitu perpustakaan sekolah. Selanjutnya, hambatan yang terjadi dalam proses pembelajaran yaitu keterbatasan sumber informasi atau buku-buku teks penunjang tentang materi yang sedang dipelajarinya. Untuk mengatasi kesulitan atau hambatan tersebut, perpustakaan sekolah sangat dibutuhkan. Perpustakaan sekolah berperan dalam menjadi pusat sumber belajar dan menyediakan koleksi bahan pustaka yang akan membantu siswa dalam mencari informasi.

Perpustakaan sekolah merupakan salah satu fasilitas pendidikan yang sangat penting karena dapat memudahkan siswa untuk memperoleh informasi penting yang berhubungan dengan tugas-tugas sekolahnya. Perpustakaan sekolah merupakan sumber belajar yang sangat fleksibel dalam melayani perbedaan individu dalam belajar. Siswa dengan tempo belajar lambat maupun cepat tetap dapat menjadikan perpustakaan sekolah sebagai sumber informasi dan pengetahuan. Menurut Yudi (2009: 1), peran perpustakaan sekolah dalam proses pembelajaran di sekolah sangatlah signifikan dalam mencerdaskan masyarakat penggunanya khususnya siswa. Perpustakaan sekolah akan maksimal jika didukung oleh pihak sekolah. Dengan fasilitas perpustakaan sekolah yang baik akan berpengaruh dalam membuat siswa bisa dan terbiasa belajar dengan baik. Siswa yang senang dan sering memanfaatkan perpustakaan sekolah sebagai penyedia jasa informasi dan ilmu pengetahuan, akan terbantu dalam mewujudkan prestasi dan cita-cita pendidikannya. Selanjutnya Sudarnoto (2007: 3), menyatakan bahwa dalam memanfaatkan perpustakaan dalam kegiatan pembelajaran, siswa akan mendapatkan prestasi akademik yang baik atau dengan kata lain keberhasilan prestasi akademiknya dipengaruhi oleh pemanfaatan perpustakaan sebagai sumber primer yang dapat memenuhi kebutuhan informasi belajarnya. Dapat disimpulkan bahwa dengan dimanfaatkannya perpustakaan sekolah dengan optimal maka penyelenggaraan kegiatan pembelajaran akan menjadi lebih maksimal dan berpengaruh terhadap hasil belajar siswa.

Perpustakaan sekolah sangat diperlukan di setiap satuan pendidikan, khususnya sekolah dasar karena dapat berperan sebagai sumber belajar yang dapat dimanfaatkan oleh siswa. Menurut UU Nomor 20 tahun 2003 tentang Sisdiknas, "pembelajaran adalah proses interaksi siswa dengan guru dan sumber belajar pada suatu lingkungan belajar". Pembelajaran merupakan bantuan yang diberikan guru agar dapat terjadi proses pemerolehan ilmu dan pengetahuan dengan memanfaatkan lingkungan atau fasilitas sekolah sebagai sumber belajar. Tetapi pada kenyataannya dalam proses pembelajaran, guru masih kurang optimal dalam memanfaatkan sumber belajar yang ada di sekolah. Dalam proses pembelajaran, guru masih menggunakan metode konvensional sehingga akan berpengaruh terhadap kurang maksimalnya hasil belajar siswa. Untuk mengoptimalkan hasil belajar siswa, guru sebaiknya memanfaatkan sumber belajar berupa perpustakaan sekolah dalam pembelajaran.

Menurut Fajar dalam Susanto (2013: 231), dalam pelaksanaan pembelajaran Pendidikan Kewarganegaraan menghadapi keterbatasan dan kendala terutama berkaitan dengan keterbatasan fasilitas dan sumber belajar. Hal ini sejalan dengan permasalahan yang ditemukan di SDN 82 Kota Bengkulu yaitu terbatasnya sumber informasi yang digunakan siswa dalam pembelajaran Pendidikan Kewarganegaraan. Sedangkan dalam pembelajaran Pendidikan Kewarganegaraan memerlukan banyak sumber informasi untuk menunjang kegiatan 
pembelajaran tersebut agar lebih optimal. Akibat dari terbatasnya sumber informasi dalam pembelajaran kemudian berdampak pada pemerolehan hasil belajar siswa yang dilihat dari nilai ulangan bulanan Pendidikan Kewarganegaraan kelas V SDN 82 Kota Bengkulu belum memuaskan dengan nilai ratarata 59,32 dibawah nilai ketuntasan minimal, sedangkan kriteria ketuntasan minimal dengan nilai 65. Untuk mengatasi kekurangan sumber informasi belajar, siswa dan guru dapat memanfaatkan perpustakaan sekolah karena sumber informasi atau materi pembelajaran yang dapat digunakan dalam pembelajaran Pendidikan Kewarganegaraan banyak terdapat di perpustakaan sekolah.

Guru memegang peranan yang sangat penting dalam memberikan motivasi atau semangat pada siswa untuk membaca. Untuk menarik minat siswa untuk belajar di perpustakaan sekolah, guru perlu mempersiapkan strategi atau cara-cara untuk menarik minat siswa untuk belajar di perpustakaan sekolah. Menurut Rosalin (2008: 162), usaha yang dapat dilakukan untuk meningkatkan kegemaran membaca siswa melalui perpustakaan sekolah yaitu, guru dapat bekerjasama dengan pustakawan ataupun pihak sekolah untuk menyediakan bahan bacaan yang mengandung unsur pengetahuan, informasi, dan hiburan. Bahan bacaan tersebut akan menggugah rasa ingin tahu dan minat siswa untuk membaca buku di perpustakaan sekolah. Selain itu, dapat juga dengan cara mengintegrasikan perpustakaan sekolah ke dalam pembelajaran dan juga dengan memberikan tugas tambahan kepada siswa di luar kelas, hal ini dikarenakan keterbatasan waktu untuk menerima ilmu di kelas menyebabkan siswa harus menambah dan mengingat kembali ilmu melalui kegiatan membaca, merangkum buku, dan kegiatan lainlain di perpustakaan sekolah.

Dalam mengintegrasikan perpustakaan sekolah kedalam pembelajaran, terlebih dahulu guru harus memilih materi pembelajaran yang sesuai dengan pembelajaran berbasis perpustakaan sekolah, setelah itu guru harus menganalisis waktu yang akan digunakan ketika melakukan pembelajaran di perpustakaan sekolah. Selanjutnya, dalam memilih pendekatan, model, dan teknik pembelajaran harus disesuaikan dengan pembelajaran dalam memanfaatkan perpustakaan sebagai sumber belajar.

Berdasarkan uraian di atas, maka peneliti melakukan penelitian untuk mengetahui apakah terdapat perbedaan perbedaan hasil belajar siswa dengan menggunakan strategi pemanfaatan perpustakaan sekolah sebagai sumber belajar pada bidang studi PKn di kelas V SD Negeri 82 Kota Bengkulu.

\section{METODE}

Jenis penelitian ini adalah penelitian kuantitatif. Menurut Sugiyono (2014: 8), penelitian kuantitatif dapat diartikan sebagai metode penelitian yang berlandaskan pada filsafat positivisme, digunakan untuk meneliti pada populasi atau sampel tertentu, pengumpulan data dengan menggunakan instrumen penelitian, analisis data bersifat kuantitatif/statistik, dengan tujuan untuk menguji hipotesis yang telah ditetapkan.

Penelitian ini menggunakan metode eksperimen. Menurut Winarni (2011: 48), menyatakan bahwa penelitian eksperimen merupakan penelitian memanipulasi stimuli, kondisi eksperimental, kemudian mengobservasi pengaruh akibat perlakuan. Jadi, penelitian ini merupakan penelitian untuk mengetahui perbedaan hasil belajar akibat adanya perlakuan berbeda yang diberikan kepada dua kelas, yaitu kelas eksperimen dan kelas kontrol.

Desain yang digunakan dalam penelitian ini adalah Quasi Eksperimental Design (Eksperimen semu). Menurut Sugiyono (2014: 77), Quasi Eksperimental Design mempunyai kelompok kontrol, tetapi tidak dapat berfungsi sepenuhnya untuk mengontrol variabel-variabel luar yang mempengaruhi pelaksanaan eksperimen.

Penelitian ini menggunakan jenis desain penelitian The matching Only Pretest-Posttest Control Group Design. Dua kelas diberikan perlakuan yang berbeda, sehingga terlihat 
perbedaan hasil belajar pada ranah kognitif siswa.

Populasi dalam penelitian ini adalah seluruh siswa kelas V di SD 82 Kota Bengkulu yang berjumlah 131 orang siswa. Terdiri dari kelas VA sebanyak 35 orang siswa, kelas VB sebanyak 28 orang siswa, kelas VC sebanyak 34 orang siswa, dan kelas VD sebanyak 34 orang siswa. Setelah dilakukan uji homogenitas dan dinyatakan kelas VA, VB, VC, dan VD merupakan kelas yang homogen kemudian ditentukan sampel penelitian dengan cara pengundian. Sampel dalam penelitian ini adalah kelas VA sebagai kelas eksperimen dan kelas VB sebagai kelas kontrol.

Pada penelitian ini, instrumen yang digunakan adalah lembar tes dalam bentuk lembar soal pilihan ganda (multiple choice) yaitu berupa lembar tes sebelum (pretest) dan sesudah (posttest) setelah mengikuti pembelajaran PKn dengan memanfaatkan perpustakaan sekolah dalam kegiatan pembelajaran dan belajar seperti biasa dikelas tanpa memanfaatkan perpustakaan sekolah.

Instrumen penelitian ini awalnya hanya berupa kisi-kisi soal. Seluruh soal dari kisi-kisi tersebut terlebih dahulu diuji validasi isi oleh validator ahli. Selanjutnya dilakukan uji coba lapangan yang merupakan uji validasi eksternal di sekolah lain yang setara dan pada kelas yang sama. Peneliti membuat 25 butir soal uji instrumen berupa soal pilihan ganda. Berdasarkan hasil dari uji coba instrumen, maka diperoleh data validitas, reliabilitas, taraf kesukaran, dan daya beda soal uji coba soal aspek kognitif.

Teknik pengumpulan data yang digunakan peneliti untuk mengumpulkan data adalah tes dalam bentuk pretest dan posttest.

Pengolahan dan analisis data dalam penelitian ini dilakukan terhadap skor pretest dan skor posttest siswa yang meliputi analisis deskriptif, uji prasyarat analisis, dan analisis inferensial untuk pengujian hipotesis. Sebelum dianalisis menggunakan uji-t, maka terlebih dahulu perlu dilakukan uji normalitas dan homogenitas.

\section{HASIL}

\section{Deskripsi Hasil Pretest}

Data hasil belajar aspek kognitif ini adalah data yang diperoleh dari lembar pretest siswa. Pemberian lembar pretest ini dilakukan pada kedua kelas sampel yaitu kelas VA dengan memanfaatkan perpustakaan sekolah sebagai sumber belajar dalam pembelajaran dan kelas VB tanpa memanfaatkan perpustakan sekolah sebagai sumber belajar dan belajar seperti biasa di dalam kelas.

Setelah dilakukan perhitungan hasil belajar pretest siswa secara deskriptif, pada kelas eksperimen diperoleh nilai terkecil 40 dan nilai terbesar 80 sedangkan pada kelas kontrol diperoleh nilai terkecil 35 dan nilai terbesar 80 . Skor rata-rata pretest dari kedua kelas yaitu kelas eksperimen 61,20 dan kelas kontrol 57,36. Median pada kelas eksperimen sebesar 65,00 sedangkan pada kelas kontrol sebesar 60,00. Modus pada kelas eksperimen sebesar 70,00 sedangkan pada kelas kontrol sebesar 60,00. Standar deviasi pada kelas eksperimen sebesar 10,49 sedangkan pada kelas kontrol sebesar 11,77 .

\section{Deskripsi Hasil Posttest}

Data hasil belajar aspek kognitif ini adalah data yang diperoleh dari lembar posttest siswa. Pemberian lembar posttest ini dilakukan pada kedua kelas sampel yaitu kelas VA dengan memanfaatkan perpustakaan sekolah sebagai sumber belajar dalam pembelajaran dan kelas VB tanpa memanfaatkan perpustakan sekolah sebagai sumber belajar dan belajar seperti biasa di dalam kelas. Setelah dilakukan perhitungan hasil belajar pretest siswa secara deskriptif, pada kelas eksperimen diperoleh nilai terkecil 65 dan nilai terbesar 100 sedangkan pada kelas kontrol diperoleh nilai terkecil 50 dan nilai terbesar 90 . Skor rata-rata pretest dari kedua kelas yaitu kelas eksperimen 84,47 dan kelas kontrol 70,25. Median pada kelas eksperimen sebesar 85,00 sedangkan pada kelas kontrol sebesar 70,00. Modus pada kelas eksperimen sebesar 80,00 dan 90,00 sedangkan pada kelas kontrol sebesar 80,00. Standar deviasi pada kelas eksperimen 
sebesar 8,79 sedangkan pada kelas kontrol sebesar 11,19 . Selanjutnya data disusun dalam distribusi frekuensi.

\section{Hasil Uji Normalitas}

Pengujian normalitas bertujuan untuk mengetahui apakah hasil pretest dan posttest kelas sampel pada penelitian ini berdistribusi normal atau tidak. Dalam penelitian ini pengujian normalitas dilakukan dengan menggunakan uji Chi Kuadrat. Suatu data dikatakan berdistribusi normal jika hasil perhitungan diperoleh nilai jika $x^{2}{ }_{\text {hitung }}<x_{\text {tabel. }}^{2}$.

Berdasarkan data hasil pretest pada kelas eksperimen dan kelas kontrol menunjukkan bahwa nilai $x^{2}{ }_{\text {hitung }}$ pada kelas eksperimen sebesar 8,31 dan nilai $x^{2}{ }_{\text {hitung }}$ pada kelas kontrol sebesar 4,87 . Nilai $x^{2}$ tabel pada taraf signifikan $5 \%$ sebesar 11,07 . Artinya $x^{2}{ }_{\text {hitung }}<x^{2}$ tabel. Hasil ini memberikan indikasi bahwa hasil belajar pretest sampel penelitian berdistribusi normal.

Berdasarkan data hasil posttest pada kelas eksperimen dan kelas kontrol menunjukkan bahwa nilai $x^{2}$ hitung pada kelas eksperimen sebesar 4,61 dan nilai $x^{2}{ }_{\text {hitung }}$ pada kelas kontrol sebesar 4,03 . Nilai $x^{2}$ tabel pada taraf signifikan $5 \%$ sebesar 11,07. Artinya $x^{2}{ }_{\text {hitung }}<x^{2}$ tabel .

Hasil ini memberikan indikasi bahwa hasil belajar posttest sampel penelitian berdistribusi normal.

\section{Hasil Uji Homogenitas}

Setelah melakukan uji normalitas pada hasil belajar pretest dan posttest, selanjutnya dilakukan uji homogenitas menggunakan uji $\mathrm{F}$. Sampel dikatakan memiliki varian homogen apabila $\mathrm{f}_{\text {hitung }}$ lebih kecil dari pada $\mathrm{f}_{\text {tabel }}$ pada taraf signifikan 5\%. Secara metematis dituliskan $\mathrm{f}_{\text {hitung }}<\mathrm{f}_{\text {tabel }}$ pada derajat kebebasan (dk) pembilang (varian terbesar) dan derajat kebebasan (dk) penyebut (varian terkecil).
Berdasarkan data yang diperoleh dari hasil pretest pada kelas eksperimen dan kelas kontrol menunjukkan bahwa nilai $\mathrm{f}_{\text {hitung }}$ sebesar 1,26 lebih kecil daripada nilai $\mathrm{f}_{\text {tabel }}$ pada taraf signifikan 5\% sebesar 1,86. Pada hasil posttest pada kelas eksperimen dan kelas kontrol menunjukkan bahwa nilai $\mathrm{f}_{\text {hitung }}$ sebesar 1,62 lebih kecil daripada nilai $\mathrm{f}_{\text {tabel }}$ pada taraf signifikan 5\% sebesar 1,86. Artinya $\mathrm{f}_{\text {hitung }}<\mathrm{f}_{\text {tabel }}$.

Hasil ini memberikan indikasi bahwa hasil belajar pretest dan posttest kelas eksperimen berasal dari varian yang homogen.

\section{Hasil Uji Hipotesis}

Pengujian hipotesis dilakukan untuk mengetahui perbedaan hasil belajar siswa dengan menggunakan strategi pemanfaatan perpustakaan sekolah sebagai sumber belajar pada bidang studi PKn di kelas V SD Negeri 82 Kota Bengkulu. Pengujian dilakukan dengan membandingkan hasil belajar kognitif siswa yang melakukan pembelajaran dengan memanfaatkan perpustakaan sekolah sebagai sumber belajar dengan hasil belajar kognitif siswa yang hanya belajar di kelas tanpa memanfaatkan perpustakaan sekolah sebagai sumber belajar.

Pengujian ini akan menguji hipotesis sebagai berikut:

$\mathrm{H}_{0}=$ Tidak terdapat perbedaan hasil belajar siswa dengan menggunakan strategi pemanfaatan perpustakaan sekolah sebagai sumber belajar pada bidang studi PKn di kelas V SD Negeri 82 Kota Bengkulu.

$\mathrm{H}_{\mathrm{a}}=$ Terdapat perbedaan hasil belajar siswa dengan menggunakan strategi pemanfaatan perpustakaan sekolah sebagai sumber belajar pada bidang studi PKn di kelas V SD Negeri 82 Kota Bengkulu.

Pengujian hipotesis penelitian dilakukan dengan menggunakan uji-t. Kriteria pengujian, apabila $t_{\text {hitung }}>t_{\text {tabel }}$ berarti $\mathrm{H}_{0}$ ditolak dan $\mathrm{H}_{\mathrm{a}}$ diterima, sebaliknya, jika $t_{\text {hitung }}<t_{\text {tabel }}$ berarti berarti $\mathrm{H}_{0}$ diterima dan $\mathrm{H}_{\mathrm{a}}$ ditolak.

Hasil pengujian hipotesis terhadap kedua sampel untuk data hasil belajar pretest, menunjukkan bahwa nilai $t_{\text {hitung }}$ sebesar 1,36 lebih kecil daripada nilai $t_{\text {tabel }}$ pada taraf 
signifikan 5\% yaitu sebesar 2,00. Artinya sebelum dilakukan kegiatan eksperimen tidak terdapat perbedaaan hasil belajar siswa. Hasil pengujian hipotesis terhadap kedua sampel untuk data hasil belajar posttest, menunjukkan bahwa nilai $t_{\text {hitung }}$ sebesar 5,64 lebih besar daripada nilai $\mathrm{t}_{\text {tabel }}$ pada taraf signifikan 5\% yaitu sebesar 2,00. Karena nilai $t_{\text {hitung }}(5,64)>t_{\text {tabel }}(2,00)$ berarti $H_{0}$ ditolak dan $\mathrm{H}_{\mathrm{a}}$ diterima, artinya terdapat perbedaan hasil belajar siswa dengan mengunakan strategi pemanfaatan perpustakaan sekolah sebagai sumber belajar pada bidang studi PKn di kelas V SD Negeri 82 Kota Bengkulu.

\section{PEMBAHASAN}

Berdasarkan deskripsi hasil penelitian dan uji hipotesis yang telah dilakukan menunjukkan bahwa terdapat perbedaan hasil belajar pada siswa antara kelas eksperimen yang memanfaatkan perpustakaan sekolah sebagai sumber belajar dengan kelas kontrol yang tidak memanfaatkan perpustakaan sekolah sebagai sumber belajar. Hal ini ditunjukkan dari hasil analisis menggunakan Uji perbedaan rata-rata hasil belajar siswa, dimana nilai $t_{\text {hitung }}(5,64)$ lebih besar dari nilai $\mathrm{t}_{\text {tabel }}$ pada taraf signifikansi $5 \%(2,00)$. Selain itu, terdapat perbedaan hasil belajar pretest dan posttest yang menunjukkan bahwa rata-rata hasil belajar kelas eksperimen lebih besar dibandingkan kelas kontrol. Hal tersebut dibuktikan dengan hasil rata-rata perhitungan awal pada saat pretest siswa pada kelas eksperimen yaitu 61,20 sedangkan pada kelas kontrol yaitu 57,36. Kemudian setelah dilaksanakannya pembelajaran dengan memberikan perlakuan yang berbeda pada kelas eksperimen dan kelas kontrol, terdapat perbedaan hasil belajar pada kedua kelas tersebut. Setelah diberikan posttest nilai rata-rata pada kelas eksperimen yaitu 84,47 , sedangkan nilai rata-rata pada kelas kontrol yaitu 70,25. Hal ini menunjukkan bahwa setelah melakukan pembelajaran dengan menggunakan strategi dalam memanfaatkan perpustakaan sekolah sebagai sumber belajar, siswa memiliki skor ratarata lebih tinggi daripada sebelum melakukan pembelajaran tanpa memanfaatkan perpustakaan sekolah sebagai sumber belajar.

Pembelajaran dengan memanfaatkan perpustakaan sekolah sebagai sumber belajar dapat membantu siswa untuk belajar dengan lebih cepat. Seperti yang diungkapkan oleh Sudarnoto (2007: 3), bahwa dalam memanfaatkan perpustakaan dalam kegiatan pembelajaran, siswa akan mendapatkan prestasi akademik yang baik atau dengan kata lain keberhasilan prestasi akademiknya sangat dipengaruhi oleh pemanfaatan perpustakaan sebagai sumber primer yang dapat memenuhi kebutuhan informasi belajarnya. Berdasarkan hasil penelitian, setelah mengikuti pembelajaran dengan memanfaatkan perpustakaan sekolah sebagai sumber belajar, sebanyak 33 orang siswa mendapatkan nilai $\geq 70$, dan hanya 2 orang siswa yang mendapatkan nilai di bawah 70 . Hal ini dimungkinkan karena dengan siswa memanfaatkan perpustakaan sekolah sebagai sumber belajar dalam kegiatan pembelajaran, siswa dapat memperoleh berbagai macam sumber informasi yang terkait dengan materi pembelajarannya dan tidak terpaku hanya pada buku teks saja.

Pemanfaatan perpustakaan juga erat kaitannya dengan tahapan berpikir siswa SD khususnya siswa kelas tinggi yang dalam penelitian ini adalah kelas $\mathrm{V}$, yang sedang dalam fase operasional konkret yaitu siswa sudah mulai gemar membaca buku-buku (Fudyartanta, 2011: 198). Dengan memanfaatkan perpustakaan sekolah, dapat memberikan pembelajaran yang bermakna kepada siswa, karena siswa akan mendapatkan pengetahuan yang lebih luas dengan membaca buku yang ada di perpustakaan sekolah. Selain itu, siswa juga tidak akan kekurangan bahan sumber belajar sehingga siswa banyak memiliki referensi dan dapat meningkatkan ilmu pengetahuan siswa.

Dalam mengintegrasikan perpustakaan sekolah ke dalam pembelajaran, terlebih dahulu peneliti menyusun dan menerapkan strategi pembelajaran atau prosedur pembelajaran yang sesuai dengan materi pembelajaran. Seperti yang diungkapkan oleh Jihad dan Haris (2012: 23), menjelaskan bahwa bila guru hendak mengajarkan suatu mata pelajaran maka tuntutan 
yang akan muncul adalah guru harus memilih dan menyesuaikan strategi pembelajaran yang meliputi pendekatan, metode, teknik pembelajaran yang sesuai dengan materi yang akan diajarkan, agar tujuan pembelajaran dapat tercapai secara optimal. Dalam mengintegrasikan perpustakaan sekolah ke dalam pembelajaran, peneliti menggunakan pendekatan Scientific, model pembelajaran Discovery Learning, dan metode diskusi, tanya jawab dan penugasan.

Dalam penelitian ini, perpustakaan sekolah diberdayakan secara optimal dalam mendukung proses pembelajaran di sekolah. Dengan demikian, proses pembelajaran tidak hanya berpusat pada guru, tetapi juga berpusat pada informasi (berbagai ilmu pengetahuan) yang tersedia di perpustakaan sekolah. Perpustakaan sekolah dapat menjadi sumber belajar bagi siswa agar siswa dapat belajar lebih mandiri dan bertanggung jawab.

Dilihat dari hasil penelitian yang telah dilakukan di kelas eksperimen, dapat dinyatakan bahwa pemanfaatan perpustakaan sekolah sebagai sumber belajar dapat menjadikan pembelajaran lebih efektif serta dapat meningkatkan motivasi belajar siswa karena dalam kegiatan pembelajaran dengan memanfaatkan perpustakaan sekolah, guru menyusun dan menerapkan strategi pembelajaran atau prosedur pembelajaran yang meliputi dari pendekatan, model, dan metode pembelajaran. Dengan di manfaatkannya perpustakaan sekolah dengan optimal oleh guru, pembelajaran tidak lagi hanya berpusat pada guru, tetapi adanya buku-buku sumber yang tersedia di perpustakaan sekolah dapat membuat siswa belajar lebih mandiri.

Sedangkan pada kelas kontrol, proses pembelajaran kurang efisien bila dibandingkan dengan kelas eksperimen. Hal ini dikarenakan siswa pada kelas kontrol melakukan pembelajaran secara konvensional dan hanya terpaku pada satu buku teks saja.

Selain itu, pemberian posttest dengan soal yang sama setelah pembelajaran berlangsung menunjukkan bahwa hasil posttest yang diperoleh oleh siswa pada kelas eksperimen dan kelas kontrol terlihat berbeda. Nilai posttest pada kelas eksperimen lebih tinggi dibandingkan dengan nilai kelas kontrol. Padahal sebelum pembelajaran berlangsung, kedua kelas samasama diberikan pretest dengan soal yang sama dan mengikuti pembelajaran yang secara keseluruhan sama kecuali pemanfaatan perpustakaan sekolah sebagai sumber belajar pada kelas eksperimen. Berdasarkan uji hipotesis menggunakan uji-t didapat nilai $t_{\text {hitung }}(5,64)$ lebih besar dari nilai $\mathrm{t}_{\text {tabel }}$ pada taraf signifikansi $5 \%$ $(2,00)$ yang artinya $H_{a}$ diterima. Maka dapat disimpulkan bahwa secara keseluruhan strategi guru dalam memanfaatkan perpustakaan sekolah sebagai sumber belajar pada kelas eksperimen memiliki pengaruh terhadap perbedaan hasil belajar Pendidikan Kewarganegaraan siswa kelas V SD Negeri 82 Kota Bengkulu.

\section{SIMPULAN}

Berdasarkan data hasil penelitian di SDN 82 Kota Bengkulu dan pengolahan data, analisis serta pembahasan maka dapat disimpulkan bahwa "terdapat perbedaan hasil belajar dengan menggunakan strategi dalam memanfaatkan perpustakaan sekolah sebagai sumber belajar pada bidang studi PKn di kelas V Negeri 82 Kota Bengkulu". Hal ini ditunjukkan dengan perhitungan uji-t perbedaan rata-rata hasil belajar siswa yaitu $\mathrm{t}_{\text {hitung }}(1,36)<\mathrm{t}_{\text {tabel }}(2,00)$ untuk pretest dan $\mathrm{t}$ hitung $(5,64)>\mathrm{t}$ tabel $(2,00)$ untuk posttest. Berarti bahwa pembelajaran dengan memanfaatkan perpustakaan sekolah sebagai sumber belajar dapat meningkatkan hasil belajar siswa dibandingkan dengan belajar di dalam kelas secara konvensional yang hanya menggunakan buku teks tertentu. Dengan memanfaatkan perpustakaan sekolah sebagai sumber belajar, siswa dapat memperoleh banyak sumber informasi yang akan meningkatkan wawasan dan pengetahuan siswa.

\section{SARAN}

Berdasarkan kesimpulan hasil penelitian, maka peneliti mengemukakan beberapa saran sebagai berikut:

1. Bagi guru agar dapat memanfaatkan perpustakaan sebagai sumber belajar pada 
saat melakukan pembelajaran. Selain

2. pembelajaran, siswa tidak lagi berpusat kepada guru, karena siswa dapat belajar secara aktif mencari dan membaca bukubuku yang ada di perpustakaan sekolah sehingga pengetahuan siswa menjadi lebih luas dan pembelajaran dapat menjadi lebih efektif.

3. Guru lebih memotivasi siswa untuk memanfaatkan perpustakaan sekolah sebagai sumber belajar baik dalam proses pembelajaran maupun di luar jam pembelajaran, karena melalui perpustakaan terdapat banyak sumber belajar dan informasi yang dapat meningkatkan wawasan dan pengetahuan siswa.

\section{DAFTAR PUSTAKA}

Departemen Pendidikan Nasional, 2005. Peraturan Pemerintah Nomor 19 Tahun 2005, tentang Standar Nasional Pendidikan. Jakarta: Depdiknas.

Departemen Pendidikan Nasional, 2003. UndangUndang Nomor 20 Tahun 2003, Tentang Sistem Pendidikan Nasional. Jakarta: Depdiknas. memudahkan guru dalam kegiatan Fudyartanta, Ki. 2011. Psikologi Perkembangan. Yogyakarta: Universitas Terbuka.

Jihad, Asep \& Haris, Abdul. 2013. Evaluasi Pembelajaran. Yogyakarta: Multi Pressindo.

Rosalin, Elin. 2008. Pemanfaatan Perpustakaan dan Sumber Informasi. Bandung: PT Karsa Mandiri Persada.

Sudarnoto, Abdul Hakim. 2007. Perpustakaan dan Pendidikan Pemetaan Peran Serta Perpustakaan dalam Proses Belajar Mengajar. Jakarta: Fakultas Adab dan Humaniora UIN Jakarta.

Sugiyono, 2014. Metode Penelitian Kuantitatif Kualitatif dan $R \& D$. Bandung: Alfabeta.

Susanto, Ahmad. 2013. Teori Belajar dan Pembelajaran di Sekolah Dasar. Jakarta: Kencana Prenadamedia Group.

Winarni, Endang Widi. 2011. Penelitian Pendidikan. Bengkulu: Unit Penerbitan FKIP Unib.

Yudi, C Teguh. 2009. Peran Perpustakaan Sekolah dalam Mencetak Siswa Berprestasi. Jurnal Perpustakaan Sekolah (Nomor 1978-9548). Hlm. 1-13 